\title{
Was Labour Penalised where it Stood All Women Shortlist Candidates? An Analysis of the 2010 UK General Election
}

\author{
David Cutts and Paul Widdop
}

Despite losing nearly 100 seats, Labour managed to increase its percentage of women MPs in parliament due to the success of all women shortlists (AWS). However, 35 AWS candidates were defeated. So was Labour penalised where it stood AWS candidates or was any backlash symptomatic of Labour's electoral predicament or the result of being a new candidate in a seat? Here we examine whether AWS candidates fared worse than other Labour candidates in the 2010 general election. Our findings suggest that AWS candidates suffered from being new candidates. Both AWS and non-AWS candidates in Labour-held seats fared significantly better than AWS and new candidates in non-held seats. But there was no significant difference in support between AWS and new non-AWS candidates standing in incumbent seats or between AWS and new candidates in non-held Labour seats. Put simply, there was no anti-AWS effect, even after taking account of incumbency status, in the 2010 general election.

Keywords: all women shortlists; Labour; 2010 general election; new candidate effect

\section{Introduction}

The election of 142 women to the House of Commons at the 2010 general election represented a net gain of 2.5 per cent from five years earlier. Women now constitute more than 20 per cent of all MPs. Yet this headline figure still hides disparities between the parties despite Labour losing nearly 100 parliamentary seats and all the three main parties publicly committing to increasing the diversity of their candidates (Campbell and Childs 2010; Childs 2010). While all parties engaged in equality rhetoric, both the Liberal Democrats and the Conservatives also adopted equality promotion. Given the Liberal Democrats' perennial problem of insufficient supply, party efforts largely consisted of a sex quota at the shortlisting stage of the candidate selection process and internal strategies to ensure that the gender balance was adhered to on the assumption that minimum standards were met (Childs 2010). The Conservatives under David Cameron created a priority list of candidates, known as the A-list, 50 per cent of which were guaranteed to be women. Further measures such as the use of primaries in the candidate selection process and a 50:50 sex quota during the shortlisting stage also heightened expectation that the 2010 general election would enhance women's representation in parliament (Campbell and Childs 2010; Childs 2010; Squires 2010). These equality strategies provided 
mixed results. While the Liberal Democrats saw its number of women representatives fall to seven, the Conservatives more than doubled their number of women elected to 48. However, they failed to meet their pre-election target of 60 women MPs (Campbell and Childs 2010).

Unlike the other two main parties, Labour remained committed to the logic of equality guarantees in the 2010 general election through the implementation of all women shortlists (AWS). Labour was unwilling, both for perceived electoral reasons and because of its long-term goal of parity of representation between women and men at Westminster, to relinquish the issue of 'women's numerical representation', an issue they had owned since 1997. The decision by Labour to persevere with AWS in 2010 occurred despite the hugely embarrassing loss of Blaenau Gwent five years earlier to an independent candidate, Peter Law, who stood against the official Labour candidate in the party stronghold after she had been selected on an AWS. 'This is what happens when you don't listen', proclaimed Law as he famously overturned a huge Labour majority in the seat. This highprofile loss overshadowed the electoral success of 23 of the 30 AWS candidates selected in 2005 and stimulated a post-election debate about how candidates should be selected within the Labour party, across the political spectrum and in the electorate at large (Cutts et al. 2008). However, in 2010, AWS remained a central plank of Labour's candidate selection strategy, with more than half of AWS candidates selected in retirement seats. The party hierarchy also placed a greater emphasis on managing their relationship with local parties in a conscious attempt to avoid a repeat of the Blaenau Gwent debacle five years earlier (Campbell and Childs 2010). In the 2010 general election, Labour lost nearly 100 seats and saw its number of women MPs decline from 98 to 81. Yet, Labour increased its percentage of women MPs in parliament to 31 per cent, nearly twice that of the Conservatives, and still has more women MPs than all of the other parties in parliament (Campbell and Childs 2010). Much of this is due to the success of AWS, which again contributed 29 elected Labour women MPs. However, 35 AWS candidates standing in both incumbent seats and non-incumbent seats were defeated. So did Labour suffer a post-Blaenau Gwent backlash in 2010? Was Labour penalised where it stood AWS candidates? Was any backlash symptomatic of Labour's electoral predicament or simply the result of being a new candidate in a seat?

In this article, we examine whether AWS candidates fared worse than other Labour candidates in the 2010 general election. Apart from the wider fallout from Blaenau Gwent and the possibility of public dissatisfaction expressed elsewhere against AWS candidates, there are two other reasons for examining whether Labour suffered any electoral consequences from AWS in 2010. First, the electoral context was different from previous elections with Labour widely expected to lose the general election. The operation of an overtly defensive electoral strategy to limit its losses, even in fairly safe seats, was in stark contrast to previous elections (Fisher et al. 2011). Second, Labour's AWS policy also differed from five years earlier, which warrants closer inspection. AWS was not just limited to incumbent seats (as in 2005) but, on the basis of marginality, included possible winnable seats, although in the context of the election these were highly unlikely. Hence, we not only examine whether Labour suffered an AWS backlash, but also whether its performance differed by incumbent and non-incumbent seats. 
Initially our goal is descriptive-outlining the number of AWS candidates and specific seat types and in particular providing some descriptive statistical evidence. After discussing the large number of retirements following the expenses scandal, we suggest that the selection of seats may not be random and discuss the need to take this into account during the modelling process. We then detail possible modelling options to eliminate selection bias before describing the problems of using such models here given the data available. Although such model approaches were not feasible, we do stress that preliminary testing revealed that 'being an AWS seat' was not unduly biased by the existence of confounding factors. Using an ordinary least squares (OLS) modelling approach, we first examine the effect of candidate sex by comparing all AWS candidates with female incumbent candidates that are nonAWS. We then repeat the model differentiating between those AWS candidates who were selected in incumbent and non-incumbent seats. While we find no evidence of a sex effect, those AWS candidates selected in non-incumbent seats did worse than other candidates when previous vote share was controlled for. We then hypothesised that any AWS effect could simply be a new candidate effect. Further regression models were run to establish if this was the case and there was also an attempt to differentiate between an AWS effect and a new candidate effect. Our findings suggest that AWS candidates largely suffered from being new candidates rather than from any anti-AWS effect. However, AWS candidates in Labour-held seats fared significantly better than those in non-held seats even after controlling for prior vote share. New non-AWS incumbents also performed significantly better than new non-AWS candidates standing in non-incumbent seats. But while AWS candidates in Labour-held seats did perform better than new non-AWS candidates in similar seats, there was no significant difference between the two variables. There was also no significant difference in support between AWS and new non-AWS candidates standing in non-incumbent seats even after controlling for prior vote. Put simply, even after taking account of incumbent seat status, there was no evidence of an anti-AWS effect. We conclude by emphasising the positive legacy of AWS and the substantive benefits it has brought. Despite the equality rhetoric and promotion of the Conservatives and the Liberal Democrats, the 2010 election result once again proved that only through Labour's strategy of equality guarantees will women's opportunities further improve and the long-term objective of parity of representation between women and men at Westminster be met.

\section{The Story of AWS 1997-2010}

The Labour party first introduced AWS for the selection of parliamentary candidates at the 1997 general election. In 1996, Labour was found by an industrial tribunal to be in breach of the 1975 Sex Discrimination Act and was forced to cease the selection of candidates based on AWS (Childs 2003). Despite the premature ending of the policy, those candidates who had been selected by AWS prior to the ruling retained their position. Of the 38 AWS candidates who stood in 1997, only three were unsuccessful. Leaving aside the normative case for a politics of presence (Phillips 1995; Mansbridge 1999)_justice reasons, symbolic representation and substantive reasons such as women expressing a different set of values and concerns (Phillips 1998; Childs 2004)—the election of 101 women in 1997 aided by AWS enabled Labour to look progressive. It also had longer-term political and electoral 
consequences. The emergence of gender voting gaps in Labour's favour post-1997 (Campbell and Lovenduski 2005) and growing evidence that the presence of increasing numbers of women led to the implementation of policies that appealed directly to women (Childs 2004 and 2008) enhanced Labour's electoral popularity especially among younger women. Despite the absence of AWS in 2001, a Labour landslide ensured that 95 women were elected by the party, although this number was down on 1997 which suggests that there was no self-sustaining momentum.

New legislation was introduced in 2002 amending the 1975 Act and legalising AWS once again in time for the 2005 general election. Labour then adopted AWS for the selection of candidates, setting a goal of 35 per cent women MPs for the 2005 parliament. Thirty Labour women were selected on AWS in 2005, of which 10 were in early retirement seats and 20 were selected post-December 2002 (Cutts et al. 2008). All challenger seats were open shortlists. Despite the election of 23 women by AWS in 2005, the defeat of AWS candidate Maggie Jones in the traditional Labour stronghold of Blaenau Gwent largely overshadowed Labour's achievement of increasing both its number and percentage of women MPs. Fighting the election on an explicitly anti-AWS ticket, ex-Labour Welsh AM Peter Law overturned a 19,000 Labour majority in the most high-profile defeat of an AWS candidate. While scholarly evidence suggested that there was probably something more than a simple AWS factor at work (Cutts et al. 2008), less publicised, albeit smaller, defeats occurred for six other AWS women. Six of the seven losses were in late retirement seats and occurred in the most vulnerable AWS seats. Given this, scholars then questioned whether the events in Blaenau Gwent were exceptional or represented a wider dissatisfaction among the electorate with Labour's AWS policy (Cutts et al. 2008). While descriptive evidence suggested the latter (Curtice et al. 2005), another group of scholars questioned the perceived wisdom of an AWS backlash against Labour and established that there was no significant anti-AWS effect that proved detrimental to Labour in 2005; being a new candidate was far more important and one masked by AWS (Cutts et al. 2008).

Post-2005, Labour risked losing its ownership of the women's representation issue. Under David Cameron, the Conservatives placed the selection of women candidates at the heart of its modernisation agenda. Not only did they introduce reforms that would increase the chances of women being selected; Cameron, albeit belatedly, seemed to embrace AWS for candidate selection in early 2010 although none were forthcoming. Labour, by contrast, found it difficult to step out of the shadow of the Blaenau Gwent debacle. The death of the elected Independent Peter Law in April 2006 prompted an apology from the Welsh secretary, Peter Hain, for Labour's imposition of AWS in Blaenau Gwent at the previous general election. Yet, Labour still lost the Westminster by-election (where they selected a non-AWS candidate) to the Independent Dai Davies while Trish Law, the wife of the late Peter Law, won the Welsh Assembly seat. Despite the setback in Blaenau Gwent, Labour pressed ahead with the adoption of AWS in the run-up to the 2010 general election. Labour elites did attempt to learn the lessons from Blaenau Gwent by placing greater emphasis on managing their relationship with local parties than they had done during the parliamentary candidate selection process at the previous election. Yet, hard-fought intra-party battles over the selection of AWS candidates still occurred in a number 
of constituencies. Two high-profile examples were Airdrie and Shotts and Durham North West following the retirement of Labour stalwarts John Reid and Hilary Armstrong.

Sixty-four candidates were selected by AWS in 2010, 45 of whom were in incumbent seats (Table 1). Unlike in 2005, a further 19 AWS candidates were selected in challenger seats, 14 of which were marginal contests with Labour less than 5 per cent behind the incumbent (Table 2). In the 45 AWS incumbent seats, Labour made stringent efforts not to fall below the stated objective of 35 per cent women representation in each region. Fifteen AWS candidates were selected in the north of England, 13 in the Midlands and six in Scotland in an attempt to ensure that this threshold was not breached in its heartland areas. In Wales, there were two AWS candidates selected in incumbent seats although, wary of the debacle in Blaenau Gwent five years earlier, the party decided not to opt for AWS in two similar Labour strongholds, Pontypridd and Islwyn. Of the 19 AWS selections in non-incumbent seats, there were two in Wales and Scotland and three in Yorkshire and Humberside and London. Four AWS candidates were selected in the south east, all of which were seats where Labour was less than 2 per cent behind the incumbent.

The selection of 45 AWS candidates in incumbent seats partly reflected the unprecedented number of sitting Labour MPs who retired at the 2010 general election. While Labour's expected electoral defeat may have led to some early retirements, the parliamentary expenses scandal undoubtedly contributed to a number of later exits. In early May 2009, the Telegraph began publishing leaked documents containing details of MPs' allowances and expenses, some of which alleged misuse as well as permitted claims. The ensuing political scandal enveloped MPs and peers from all the major parties. Unsurprisingly, of those 45 incumbent seats that selected AWS candidates, 25 were in seats where the incumbent MP retired post-May 2009. Eight of these late retirements occurred less than five months before the 2010 general election.

\section{The 2010 General Election: Evidence of an Anti-AWS Effect?}

In the 2010 general election, AWS candidates were not immune from the electoral downturn in Labour's fortunes. Of the 64 AWS candidates, 35 were defeated. All 19 AWS candidates standing in non-incumbent seats failed to get elected, while 16 of the 45 AWS candidates seeking election in Labour's incumbent seats were also unsuccessful (see Table 3). Closer inspection of the data revealed that Labour losses occurred in fairly safe seats with 2005 majorities of in excess of 15 per cent as well as in those which were far more marginal. Eight of the 16 AWS candidates standing in Labour incumbent seats were defeated in the Midlands, which generally saw a shift in support against Labour. Some of the large swings against Labour in seats such as Keighley and Cannock Chase may have partly reflected the loss of a popular local incumbent MP who had previously enjoyed a strong personal vote. ${ }^{1}$

Notwithstanding these factors, AWS candidates (in both incumbent and nonincumbent seats) generally fared no better or worse than new candidates irrespective of sex (see Table 4). Women incumbent candidates fared better than AWS 
Table 1: All Women Shortlist Incumbent Seats: 2010 General Election

\begin{tabular}{|c|c|c|c|c|c|}
\hline AWS & 2010 seat & Region & 2005 incumbent & Sex & Retirement \\
\hline 1. & Airdrie \& Shotts & Scotland & John Reid & $M$ & Early \\
\hline 2. & Ashfield & EM & Geoff Hoon & $\mathrm{M}$ & Late \\
\hline 3. & Birmingham Ladywood & WM & Claire Short & $\mathrm{F}$ & Early \\
\hline 4. & Blackpool North \& Cleveleys & NW & Joan Humble & $\mathrm{F}$ & Late \\
\hline 5. & Bolton West & NW & Ruth Kelly & $\mathrm{F}$ & Early \\
\hline 6. & Brighton Pavilion & SE & David Lepper & $\mathrm{M}$ & Early \\
\hline 7. & Burton & WM & Janet Dean & $\mathrm{F}$ & Early \\
\hline 8. & Bury North & NW & David Chaytor & M & Late \\
\hline 9. & Calder Valley & $Y \& H$ & $\begin{array}{l}\text { Christine } \\
\text { McCafferty }\end{array}$ & $\mathrm{F}$ & Early \\
\hline 10. & Cannock Chase & WM & Tony Wright & $\mathrm{M}$ & Early \\
\hline 11. & Clwyd South & Wales & Martyn Jones & $\mathrm{M}$ & Late \\
\hline 12. & Colne Valley & $Y \& H$ & Kali Mountford & M & Early \\
\hline 13. & Dudley South & WM & Ian Pearson & $\mathrm{M}$ & Late \\
\hline 14. & Dunbartonshire West & Scotland & John McFall & $\mathrm{M}$ & Late \\
\hline 15. & Durham North West & NE & Hilary Armstrong & $\mathrm{F}$ & Late \\
\hline 16. & East Lothian & Scotland & Anne Moffat & $\mathrm{F}$ & Late \\
\hline 17. & Edinburgh East & Scotland & Gavin Strang & $\mathrm{M}$ & Early \\
\hline 18. & Erewash & EM & Liz Blackman & $\mathrm{F}$ & Late \\
\hline 19. & Erith \& Thamesmead & London & John Austin & $\mathrm{M}$ & Early \\
\hline 20. & Glasgow East & Scotland & David Marshall* & $\mathrm{M}$ & Early \\
\hline 21. & Halesowen \& Rowley Regis & WM & Sylvia Heal & $\mathrm{F}$ & Late \\
\hline 22. & High Peak & EM & Tom Levitt & M & Late \\
\hline 23. & Houghton \& Sunderland South & NE & Fraser Kemp & $\mathrm{M}$ & Early \\
\hline 24. & Keighley & $Y \& H$ & Ann Cryer & $\mathrm{F}$ & Early \\
\hline 25. & Kilmarnock \& Loudon & Scotland & Des Browne & M & Late \\
\hline 26. & Leeds West & $\mathrm{Y} \& \mathrm{H}$ & John Battle & $\mathrm{M}$ & Early \\
\hline 27. & Leicester West & EM & Patricia Hewitt & $\mathrm{F}$ & Late \\
\hline 28. & Lewisham East & London & Bridget Prentice & $\mathrm{F}$ & Early \\
\hline 29. & Liverpool Wavertree & NW & Jane Kennedy & $\mathrm{F}$ & Late \\
\hline 30. & Makerfield & NW & Ian McCartney & $\mathrm{M}$ & Late \\
\hline 31. & Newcastle upon Tyne Central & NE & Jim Cousins & M & Late \\
\hline 32. & Newcastle upon Tyne North & NE & Doug Henderson & $\mathrm{M}$ & Late \\
\hline 33. & Nottingham South & EM & Alan Simpson & $\mathrm{M}$ & Early \\
\hline 34. & Nuneaton & WM & Bill Olner & M & Early \\
\hline 35. & Sherwood & EM & Paddy Tipping & $\mathrm{M}$ & Late \\
\hline 36. & Stevenage & EEng & a Follett & $\mathrm{F}$ & Late \\
\hline 37. & Stretford \& Urmston & NW & Beverley Hughes & $\mathrm{F}$ & Late \\
\hline 38. & Sunderland Central & NE & Chris Mullin & M & Early \\
\hline 39. & Tyneside North & NE & Stephen Byers & M & Late \\
\hline 40. & Vale of Glamorgan & Wales & John Smith & $\mathrm{M}$ & Late \\
\hline 41. & Walsall South & WM & Bruce George & $\mathrm{M}$ & Late \\
\hline 42. & Walthamstow & London & Neil Gerrard & M & Early \\
\hline 43. & Washington \& Sunderland West & & Sharon Hodgsont & $\mathrm{F}$ & NA \\
\hline 44. & Wigan & NW & Neil Turner & M & Late \\
\hline 45. & Wirral South & NW & Ben Chapman & $\mathrm{M}$ & Late \\
\hline
\end{tabular}

*David Marshall stepped down in June 2008. The SNP won the July 2008 by-election in Glasgow East tSharon Hodgson was the incumbent in Gateshead East and Washington West and then was selected in the new constituency of Washington \& Sunderland West for the 2010 general election

Regions: NW, North West; SW, South West; EEng, East of England; SE, South East; WM, West Midlands; EM, East Midlands; Y\&H, Yorkshire \& Humberside 
Table 2: All Women Shortlist Non-incumbent Seats: 2010 General Election

\begin{tabular}{|c|c|c|c|c|}
\hline \multicolumn{2}{|c|}{ AWS 2010 seat } & \multirow{2}{*}{$\begin{array}{l}\text { Region } \\
\text { WM }\end{array}$} & \multirow{2}{*}{$\begin{array}{l}\text { Winning party } 2005 \\
\text { Liberal Democrats }\end{array}$} & \multirow{2}{*}{$\frac{\text { Lab behind } 05}{7.30 \%}$} \\
\hline 1. & Birmingham Yardley & & & \\
\hline 2. & Camborne \& Redruth & SW & Liberal Democrats & $7.08 \%$ \\
\hline 3. & Cardiff Central & Wales & Liberal Democrats & $15.48 \%$ \\
\hline 4. & Clwyd West & Wales & Conservatives & $0.14 \%$ \\
\hline 5. & Dunbartonshire East & Scotland & Liberal Democrats & $8.70 \%$ \\
\hline 6. & Dundee East & Scotland & SNP & $0.97 \%$ \\
\hline 7. & Finchley \& Golders Green* & London & Conservatives & $0.70 \%$ \\
\hline 8. & Gravesham & SE & Conservatives & $1.45 \%$ \\
\hline 9. & Hemel Hempstead & EEng & Conservatives & $0.37 \%$ \\
\hline 10. & Hornsey \& Wood Green & London & Liberal Democrats & $5.06 \%$ \\
\hline 11. & Ilford North & London & Conservatives & $4.13 \%$ \\
\hline 12. & Leeds North West & $Y \& H$ & Liberal Democrats & $4.96 \%$ \\
\hline 13. & Manchester Withington & NW & Liberal Democrats & $1.39 \%$ \\
\hline 14. & Reading East & SE & Conservatives & $1.71 \%$ \\
\hline 15. & Rochester \& Strood & SE & Conservatives & $1.13 \%$ \\
\hline 16. & Scarborough \& Whitby & $\mathrm{Y} \& \mathrm{H}$ & Conservatives & $2.65 \%$ \\
\hline 17. & Selby \& Ainsty & Y\&H & Conservatives & $4.31 \%$ \\
\hline & Sittingbourne \& Sheppey & SE & Conservatives & $0.05 \%$ \\
\hline 19. & Wellingborough & EM & Conservatives & $1.25 \%$ \\
\hline
\end{tabular}

*Rudi Vis won Finchley and Golders Green for Labour in 2005; however redistricting meant that Labour was notionally second in the seat

candidates as a whole and those AWS candidates standing in incumbent seats. In the latter, Labour vote share fell by more than 1.2 percentage points where there was an incumbent woman candidate. If we compare the performance of all AWS candidates standing in incumbent seats with all incumbent Labour candidates the difference is roughly 1.8 percentage points. This partly reflects the fact that male incumbent candidates fared slightly better than women. However, those AWS candidates standing in non-incumbent seats saw their vote decline by roughly 2.4 percentage points more than those selected in incumbent seats. The difference was 3.6 percentage points when compared against incumbent women candidates. Compared against all new women candidates, AWS candidates standing in nonincumbent seats saw their vote share decline by roughly an additional 2 percentage points. At first glance, these descriptive findings suggest that AWS candidates in non-incumbent seats suffered a decline in support that seems to be over and above that suffered by new women Labour candidates more generally. It also seems that there was little difference in the performance between AWS candidates who were late selections (post-May 2009) and those placed in early retirement seats (Table 4). This is perhaps surprising as we might have expected AWS candidates selected earlier in the parliament to have benefited from a longer preparation time and higher personal profile in the constituency. In fact, this was not the case, with AWS candidates in early retirement seats such as Cannock Chase just as susceptible to big swings against them as in post-May 2009 seats like Erewash and Sherwood. 
Table 3: All Women Shortlist Incumbent Seats Lost in the 2010 General Election

\begin{tabular}{|c|c|c|c|}
\hline AWS 2010 seat & Region & AWS candidate & Lab maj 2005 \\
\hline 1. Blackpool North \& Cleveleys & NW & Penny Martin & $8.48 \%$ \\
\hline 2. Brighton Pavilion & SE & Nancy Platts & $13.11 \%$ \\
\hline 3. Burton & WM & Ruth Smeeth & $4.81 \%$ \\
\hline 4. Bury North & NW & Maryam Khan & $5.05 \%$ \\
\hline 5. Calder Valley & $Y \& H$ & Stephanie Booth & $2.73 \%$ \\
\hline 6. Cannock Chase & WM & Sue Woodward & $21.00 \%$ \\
\hline 7. Colne Valley & Y\&H & Debbie Abrahams & $2.51 \%$ \\
\hline 8. Dudley South & WM & Rachel Harris & $8.91 \%$ \\
\hline 9. Erewash & EM & Cheryl Pidgeon & $15.66 \%$ \\
\hline 10. Halesowen \& Rowley Regis & WM & Sue Hayman & $9.66 \%$ \\
\hline 11. High Peak & EM & Caitlin Bisknell & $3.80 \%$ \\
\hline 12. Keighley & $Y \& H$ & Jane Thomas & $10.48 \%$ \\
\hline 13. Nuneaton & WM & Jayne Innes & $9.74 \%$ \\
\hline 14. Sherwood & EM & Emilie Oldknow & $15.91 \%$ \\
\hline 15. Stevenage & EEng & Sharon Taylor & $8.05 \%$ \\
\hline 16. Vale of Glamorgan & Wales & Alana Davies & $3.37 \%$ \\
\hline
\end{tabular}

Regions: NW, North West; SW, South West; SE, South East; WM, West Midlands; Y\&H, Yorkshire \& Humberside

\section{Examining the AWS Effect on Labour Support in 2010}

The results in Table 4 indicate that AWS candidates as a whole fared slightly worse than incumbent Labour women candidates but there was little difference between them and new candidates in other vacant seats irrespective of sex. In some ways, this is not surprising. Incumbents often garner personal support from local activism in the constituency and also tend to benefit from a higher local profile than their opponents. Often new candidates in party incumbent seats do not reap the same benefits. And this seems to have been borne out from the descriptive findings. Taking the 64 AWS candidates as a whole, any possible AWS effect may simply have been the penalty of being a new candidate. However, there is some circumstantial evidence that AWS candidates standing in nonincumbent seats did slightly worse than other new Labour candidates standing in other vacant seats. Here sex or new candidate status does not seem to offer a plausible explanation. To provide a much stronger indication of these possible relationships we need to take account of other intervening variables through a series of multivariate analyses. Hence, we combine socio-demographic and contemporary factors to examine the possible explanations of Labour support in the 2010 general election.

Here we have four working hypotheses. Our main hypothesis relates to all AWS candidates and stresses that any additional effect of being an AWS candidate in 2010 is very small and unlikely to be significant once being a new candidate is taken into account. Our second hypothesis suggests that those AWS candidates standing in 


\section{Table 4: Labour Performance in the 2010 General Election: Candidate Sex, Incumbent Seats and Candidate Sex, New Candidates and Sex, and All Women Shortlists}

\begin{tabular}{|c|c|c|}
\hline Seats and candidates & $\begin{array}{c}\text { Mean \% } \\
\text { LABVS } 2010\end{array}$ & $\begin{array}{c}\text { Mean \% } \\
\text { LABVS } \pm \text { 05-10 }\end{array}$ \\
\hline \multicolumn{3}{|l|}{ Labour candidate sex } \\
\hline All Labour woman candidates (192) & 33.17 & -6.71 \\
\hline All Labour male candidates (438) & 30.05 & -6.42 \\
\hline \multicolumn{3}{|l|}{ Labour incumbent seats \& candidates } \\
\hline Labour incumbent seats (348) & 42.89 & -5.82 \\
\hline Labour incumbent candidates (246) & 43.65 & -5.10 \\
\hline \multicolumn{3}{|l|}{ Labour incumbent seats \& candidate sex } \\
\hline Women incumbent candidates* (72) & 41.55 & -5.66 \\
\hline Male incumbent candidates (174) & 49.40 & -4.87 \\
\hline \multicolumn{3}{|l|}{ New candidates \& sex } \\
\hline All new women candidatest (120) & 28.15 & -7.34 \\
\hline All new male candidates (264) & 20.43 & -7.44 \\
\hline \multicolumn{3}{|l|}{ New candidates: all women shortlists } \\
\hline All women shortlist candidates (64) & 37.86 & -7.61 \\
\hline All women shortlist candidates (incumbent) (45) & 41.87 & -6.90 \\
\hline All women shortlist candidates (non-incumbent) (19) & 28.34 & -9.27 \\
\hline Early incumbent retirement pre May 2009 (19)‡ & 41.73 & -6.55 \\
\hline Late incumbent retirement post May 2009 (25) & 41.55 & -6.80 \\
\hline
\end{tabular}

*Includes AWS incumbent candidates (45)

tIncludes all AWS candidates (64)

$\ddagger$ Note that early and late retirements total 44 not 45 because Sharon Hodgson was the incumbent in Gateshead East and Washington West and then was selected in the new constituency of Washington \& Sunderland West for the 2010 general election

Labour-held seats are likely to perform significantly better than other AWS candidates in non-incumbent seats. The third hypothesis states that AWS candidates standing in incumbent seats are likely to perform significantly better than other new candidates standing in non-incumbent seats but not those standing in Labourheld seats even when other controls are taken into account. The fourth hypothesis suggests that there will be no significant difference in the performance of AWS and new non-AWS candidates in non-incumbent seats and that consequently there is no evidence of an anti-AWS effect by incumbency status.

To examine these hypotheses, we first model women non-AWS candidates and AWS candidates to determine whether there was a sex effect. If no sex effect is found then we can hypothesise that any AWS effect is likely to be a new candidate effect. To evaluate this we then model AWS candidates and new Labour candidates selected in other vacant seats. We extend this analysis to differentiate between a new candidate sex effect and an AWS effect given the scholarly evidence in previous elections suggesting that seats where a previous male incumbent was replaced by a 
new female candidate they did worse than where a male incumbent was replaced by another man (Curtice et al. 2005). Any difference between these coefficients will indicate whether there was a significant additional AWS effect or not. Finally, we split the AWS candidates by those selected in incumbent and non-incumbent seats to ascertain whether the former benefited electorally and the latter suffered an additional AWS penalty. The final model compares AWS candidates in incumbent and non-incumbent seats against new candidates in other vacant seats that are similarly differentiated by incumbent seat status. Unfortunately, it was not possible to extend the analysis and examine any incumbency effect by sex because only four of the new non-AWS candidates standing in Labour-held constituencies were women.

These relationships are tested using conventional OLS regression models. However, recent evidence suggests that AWS seats are selected on the basis of particular criteria such as the proximity to other women, woman retirement, region and marginality (Cutts et al. 2008). Statistical issues such as selection bias because of the problem of unobserved heterogeneity and the possibility of endogeneity bias, where the outcome variable (Labour 2010 vote share) is determined simultaneously with other covariates (AWS 2010), may lead to bias and inconsistent coefficient estimates if not corrected (Cutts et al. 2008). Two common methods used to overcome such statistical problems are an instrumental variable (IV) approach (Angrist et al. 1996; Gerber and Green 2000) and statistical matching (Rosenbaum and Rubin 1985; Imai 2005). The effectiveness of the former is dependent on the validity of the instrumental variables used (Bound et al. 1995). Using appropriate instrumental variables such as region, retired woman MP and marginality, we attempted to run an IV model but found that these instruments lacked explanatory power when they were placed in the first stage of the equation. The use of inappropriate instrumental variables irrespective of how they are theoretically derived can itself lead to inconsistent and biased estimates. ${ }^{2}$ In this case, the instrumental variables did not prove to be relevant in accounting for the factors used in the selection of AWS seats and were deemed to be unreliable from a statistical perspective. Part of the problem in dealing with any potential endogeneity bias is the small sample size for AWS candidates, an issue made far worse when we attempt to differentiate between AWS selection in non-incumbent and incumbent seats.

Our second approach involved calculating propensity scores (the conditional probability of receiving the treatment) using a logit regression of the probability of treatment as a function of the observed covariates. The estimated model found little difference between AWS seats and non-AWS seats which questions the existence of selection bias. But such preliminary findings must be treated with caution. This method is reliant on re-estimating the propensity score until the distribution of covariates are fairly similar between the control and treatment groups. But our efforts were hindered by the small sample size of the treatment group (AWS seats) and that it is necessary to differentiate between selections in Labour-held and non-held seats. Given the unreliability of estimates and the possibility of further statistical problems if either method was used, it was decided to use conventional single-level OLS regression techniques to examine the data. 


\section{Data}

To examine whether there was an AWS effect in the 2010 general election, we use aggregate data from the BBC election and the 2010 British parliamentary constituency database. All seats are included in the analysis except the current and former Speakers' seats (Buckingham and Glasgow North East) and Thirsk and Malton where the death of a candidate meant that the parliamentary constituency election did not take place until a month or so later. Yet, in order to test our hypotheses, we need to take account of other factors that might affect Labour's 2010 electoral performance.

Social cleavages have long been established as important predictors of voting behaviour because political parties tend to do better or worse in areas depending on the people who live there (Johnston et al. 1998; Cutts 2006). Ten socio-economic variables were therefore derived from the 2001 census to reflect these established cleavages. Given evidence of collinearity between the various socio-economic variables, a principal components analysis was run and three factors were extracted that clearly described the characteristics of the parliamentary constituencies. Factor 1 captures the class structure; Factor 2 describes the level of deprivation or affluence; and Factor 3 reflects the ageing character of areas, largely rural, with a particular emphasis on those electors over the age of 60 (see Table 5). In 2005, Labour lost support in areas with large Muslim electorates because of the war in

\section{Table 5: Socio-economic Variables: Principal Components Analysis Varimax-Rotated Component Loadings}

\begin{tabular}{|c|c|c|c|}
\hline 2001 census variables & $\begin{array}{c}\text { C1 } \\
\text { 'Urban } \\
\text { working } \\
\text { class' }\end{array}$ & $\begin{array}{c}\text { C2 } \\
\text { 'Deprivation/ } \\
\text { affluence' }\end{array}$ & $\begin{array}{c}\text { C3 } \\
\text { 'Retirement \& } \\
\text { rurality' }\end{array}$ \\
\hline$\%$ Agriculture & - & - & 0.82 \\
\hline \% Employers (NSEC 1 \& 2) & -0.86 & -0.33 & - \\
\hline$\%$ Degree & -0.93 & - & - \\
\hline$\%$ Non-white & -0.33 & 0.57 & -0.46 \\
\hline$\%$ Lone parents & 0.33 & 0.81 & -0.30 \\
\hline$\%$ Manufacturing & 0.82 & - & - \\
\hline$\%$ Owner occupation & - & -0.89 & - \\
\hline$\%$ Pensioners & - & -0.32 & 0.77 \\
\hline $\begin{array}{l}\% \text { Semi-routine \& routine occupations } \\
\quad \text { (NSEC } 6 \& 7 \text { ) }\end{array}$ & 0.93 & - & - \\
\hline$\%$ Unemployment & - & 0.90 & - \\
\hline Variance & $36.7 \%$ & $34.7 \%$ & $10.5 \%$ \\
\hline Accumulated value- $\%$ total variance & $36.7 \%$ & $71.4 \%$ & $81.9 \%$ \\
\hline
\end{tabular}

Notes: Components with Eigenvalues $>1$ are retained. Rotated component loadings (varimax rotation) greater than 0.3 shown 
Iraq while dissatisfaction was also widespread in areas with large student populations following the introduction of tuition fees. Five years later, the war in Iraq was a less salient issue and there was an expectation that Labour would do much better in areas with large numbers of Muslims with party identifiers returning to the Labour fold. By contrast, tuition fees were still a salient issue in constituencies with large numbers of students, particularly as the Liberal Democrats, the main opposition to Labour in many student areas, sought to mobilise the student vote through their policy of abolishing fees. Two additional variables (percentage Muslim; percentage full-time students) are therefore included to take account of such effects.

A sex of candidate variable is also included for both opposition parties. Historically, sex discrimination has been found to be operating in all of the parties' selection procedures even though scholarly evidence has shown repeatedly that there is no electoral penalty for women candidates (Lovenduski 2001). In 2010, both the main opposition parties engaged in equality rhetoric and adopted equality promotion (Campbell and Childs 2010; Childs 2010). Both the Liberal Democrats and particularly the Conservatives sought to compete more effectively against Labour for women's votes with measures to help the family and women's work/life balance the major battleground during the election. It could be that women candidates in both opposition parties substantively benefited from this more progressive outlook which is why these candidate variables are included in the regression analysis. Apart from candidate sex variables, we also take account of the parliamentary expenses scandal. The misuse of expenses by a number of sitting MPs across all parties was exposed by the media and led to widespread public dissatisfaction. As a consequence, many MPs who were implicated in the expenses scandal decided to step down from parliament while others decided to stand again in 2010. We include dummy variables for those constituencies where an MP stood down because of expenses and constituencies where an MP stood in 2010 but had made excessive expenses claims.

Local electioneering has now become an integral part of contemporary general election campaigns. The electoral impact of constituency activism has now become the 'accepted truth'. Three different groups of scholars, using different measures of campaign strength, have consistently demonstrated the electoral benefits of intensive local campaigns (Denver and Hands 1997; Whiteley and Seyd 2002; Pattie and Johnston 2009), while one scholarly team has combined these measurements of campaign effort and found that, other things being equal, the more actively a party campaigns in a constituency the more votes they win and the fewer votes their opponents get (Fieldhouse and Cutts 2009). Here we use party spending variables as a surrogate measure of local activism due to their considerable and proven validity in numerous scholarly works (Pattie and Johnston 2009).

We also include a dummy for Wales and Scotland. In Wales, the 2010 general election was still a devolution-blind event as the dividing line between Westminster and the Welsh Assembly remained distinctly blurred (Bradbury 2010). Although Labour still retained power in the Assembly, albeit in coalition with Plaid Cymru, its dominance was on the wane and there was a distinct possibility that other parties could exploit the widespread disillusionment with Labour after years of unprecedented levels of power and translate their advances made in the 2007 Assembly 
election to the Westminster election (Wyn Jones and Scully 2010). In Scotland, given the enduring unpopularity of the Conservatives and the expectation of a UK Conservative government, there was an expectation that Labour would at least maintain its strong electoral position (Mitchell and Van Der Zwet 2010). The Scottish National party (SNP) was also less relevant as a political force given the Westminster focus of the election which added to the possibility that Labour would maintain its stranglehold in Scotland in 2010.

The inclusion of demographic and contemporary controls enables us to determine the underlying pattern of support for Labour. Yet it is also important to gauge those variables that were not a reflection of support in 2005 and whether there was still an AWS effect. Hence, we fit models with prior vote share as a predictor variable. This represents an ANCOVA approach where the dependent variable becomes the change in Labour vote share not explained by previous vote share. While this is more efficient, there is actually little difference between this and a change-score approach with advantages to both approaches (Allison 1990; Fieldhouse et al. 2006).

The linear models are built incrementally to assess how the main variables of interest are affected following the introduction of other covariates. Each linear model is built over three stages. The first stage includes the main variables of interest without any additional covariates. The second stage also includes: (i) two socio-economic variables (percentage Muslim and percentage students) and three socio-economic factors that are designed to capture the social cleavages in voting patterns (Johnston et al. 1998); (ii) control variables to capture candidate sex (Conservative and Liberal Democrat); (iii) dummies for Scotland and Wales; (iv) campaign spending variables by each major political party, which act as a proxy for local campaigning; and (v) two variables to account for the fallout from the parliamentary expenses scandal. The final stage takes account of prior Labour vote share in 2005. This changes the interpretation of model by detailing the effects of other variables on Labour vote change from 2005 to 2010, where continuity of support is held constant.

\section{Did Candidate Sex or being a New Candidate Matter?}

The first part of our analysis examines whether candidate sex mattered in 2010. Both AWS candidates and women non-AWS candidates are compared against all male Labour candidates (both incumbents and new). Early scholarly literature in Britain and elsewhere suggests that voter bias may have contributed to women's lack of electoral success (Duverger 1955; Kelley and McAllister 1984; Engstrom 1987). A recent study in France also claims that the adoption of gender quotas stems from a 'male advantage' in French elections given that women are much easier to defeat at the polls than men. In other words, male incumbents have a rational incentive to support gender quotas as they have a much greater chance of being re-elected if they face a woman challenger (Guillaume et al. 2008). Other scholars have contested these findings (Murray et al. 2011) and like numerous other studies provide strong evidence to suggest that there is no overall bias against women at the polls (Norris et al. 1992; Black and Erickson 2003; Krook 2009). 
Table 6: The Impact of Candidate Sex on Labour Support in 2010 (All Seats)

\begin{tabular}{|c|c|c|c|}
\hline Variables & $\begin{array}{l}\text { Model } 1 \\
\text { AWS \& } \\
\text { sex only }\end{array}$ & $\begin{array}{c}\text { Model } 2 \\
\text { Social cleavages } \\
\text { \& contemporary } \\
\text { factors }\end{array}$ & $\begin{array}{c}\text { Model } 3 \\
\text { Previous } \\
\text { Labour } \\
\text { vote share }\end{array}$ \\
\hline Constant & $29.96^{*}$ & $30.85^{*}$ & -0.57 \\
\hline \multicolumn{4}{|c|}{ Base: All Labour male candidates (inc \& non-inc) } \\
\hline All women shortlist 2010 & $7.89^{*}$ & 0.41 & $-1.20^{*}$ \\
\hline Labour women candidates not-AWS & 0.87 & -0.27 & 0.23 \\
\hline \multicolumn{4}{|l|}{ Opposition candidates } \\
\hline Gender Conservative candidate 2005 & & 0.55 & 0.34 \\
\hline Gender Lib Dem candidate 2005 & & 0.07 & 0.33 \\
\hline Scotland & & $6.91^{*}$ & $9.25^{*}$ \\
\hline Wales & & $3.86^{*}$ & $2.16^{*}$ \\
\hline \multicolumn{4}{|l|}{ Expenses } \\
\hline Scandal where MP not standing & & 0.01 & 0.46 \\
\hline Moderate/excessive claims by sitting MP & & -0.39 & -0.09 \\
\hline \multicolumn{4}{|l|}{ Social cleavages } \\
\hline FAC1: Urban working class & & $2.77^{*}$ & -0.41 \\
\hline FAC2: Deprivation & & $6.85^{*}$ & $1.94^{*}$ \\
\hline FAC3: Retirement \& rural & & $-4.23^{*}$ & $-0.58^{*}$ \\
\hline Muslim \% & & $-0.21^{*}$ & $0.22^{*}$ \\
\hline Full time students $\%$ & & 0.03 & 0.04 \\
\hline \multicolumn{4}{|l|}{ Local campaign } \\
\hline Labour spending & & $0.18^{*}$ & $0.05^{*}$ \\
\hline Conservative spending & & $-0.09^{*}$ & $-0.02^{*}$ \\
\hline Lib Dem spending & & $-0.09 *$ & $-0.02^{*}$ \\
\hline \multicolumn{4}{|l|}{ Previous vote share } \\
\hline \% Labour vote share 2005 & & & $0.79^{*}$ \\
\hline $\mathrm{R}^{2}$ & 0.02 & 0.84 & 0.94 \\
\hline
\end{tabular}

Notes: Unstandardised coefficients, ${ }^{*} P<0.05 . \mathrm{N}=629$. Models do not include Buckingham, Glasgow NE and Thirsk \& Malton

The results of the candidate sex models are shown in Table $6 .{ }^{3}$ During the second stage of the model, the $\mathrm{R}^{2}$ values inform us that the inclusion explanatory variables explain 84 per cent of the variation in 2010 Labour vote share. This increases to 94 per cent when previous Labour vote share is added. After controlling for social cleavages and other factors, there is no evidence of a candidate sex effect. The inclusion of prior Labour vote share in 2005 does suggest that Labour did slightly worse in constituencies where it selected AWS candidates. However, while there is the possibility of an anti-AWS effect, albeit circumstantial evidence at this stage, there is little doubt that candidate sex did not matter.

A priori expectations concerning the effects of explanatory variables designed to capture the importance of socio-economic cleavages are generally borne out in the 
results. In 2010, Labour did better in urban working-class and deprived areas and significantly worse in rural and retirement constituencies and areas with a large Muslim population. However, Labour improved its performance in highly populated Muslim constituencies when prior vote share is taken into account. In 2005 , the salience of the war in Iraq meant that Labour lost support in these constituencies, mostly to the Liberal Democrats who adopted an anti-war stance. Five years later, there is evidence that voters in constituencies with a large Muslim population returned to the Labour fold. There is also evidence that Labour did not suffer any further significant reductions in university seats. Even when accounting for prior vote share, this variable was insignificant. Labour performed strongly in its heartland areas of Scotland and Wales and in constituencies where it campaigned hard. Intensive opposition campaigning did erode Labour support, but Labour activism had a significant positive effect, even when previous vote share was added to the model. Where either the Conservatives or Liberal Democrats fielded a woman candidate they failed to have a significant effect on Labour support. Similarly, there was no evidence that the parliamentary expenses scandal had an impact on the Labour vote in 2010. By contrast, prior Labour vote share was positive and significant which suggests that Labour performed best where it previously had most support.

Like 2005, there is no evidence of candidate sex effect but Labour support declined where the party stood AWS candidates. However, given previous evidence (Cutts et al. 2008), this could simply be a new candidate effect given that AWS candidates are new candidates. Here we test this hypothesis using linear regressions with the model findings reported in Table 7. ${ }^{4}$ Both AWS candidates (new candidates selected by AWS) and new non-AWS candidates (new candidates in vacant seats) are compared against all Labour incumbent non-AWS candidates (male and female). All the covariates added at the second and third stage of the model behave in the same manner as in Table 6, while the variance explained $\left(\mathrm{R}^{2}\right)$ increased slightly to 87 per cent in model 2 and 95 per cent in model 3.

In the first two stages of the model, both AWS candidates and new non-AWS candidates had a significant negative impact on Labour vote share when compared against incumbent candidates. The latter was far more substantial than the former. Following the inclusion of prior vote share, both AWS and new non-AWS candidates were negative and significant, confirming earlier findings that new candidates performed worse than incumbent candidates. A closer inspection of the results revealed that there was no additional penalty for being an AWS candidate. Indeed, the penalty of being a new non-AWS candidate on Labour support in 2005 relative to 2001 was roughly .54 (the difference between -2.97 and -2.39 ) although this was not statistically different from being an AWS candidate. It was also possible to examine whether there was a sex effect for new non-AWS candidates when compared against AWS candidates. The model was rerun with new non-AWS candidates separated by sex. After the inclusion of all the controls and prior vote share, new non-AWS women candidates (-2.67) fared slightly better than new male candidates $(-2.97)$ but marginally worse than AWS candidates (-2.39). While all three coefficients are significantly different to the base category (Labour incumbent candidates) they are not statistically different from each other. 
Table 7: The Impact of AWS and New Non-AWS Candidates on Labour Support in 2010 (All Seats)

\begin{tabular}{|c|c|c|c|}
\hline Variables & $\begin{array}{c}\text { Model } 1 \\
\text { AWS \& new } \\
\text { candidates } \\
\text { only }\end{array}$ & $\begin{array}{c}\text { Model } 2 \\
\text { Social cleavages } \\
\text { \& contemporary } \\
\text { factors }\end{array}$ & $\begin{array}{l}\text { Model } 3 \\
\text { Previous } \\
\text { Labour } \\
\text { vote share }\end{array}$ \\
\hline Constant & $43.65^{*}$ & $36.62^{*}$ & $3.68^{*}$ \\
\hline \multicolumn{4}{|c|}{ Base: Labour incumbent Candidates (male \& female/no AWS) } \\
\hline All women shortlist 2010 & $-5.80^{*}$ & $-2.54^{*}$ & $-2.39 *$ \\
\hline $\begin{array}{l}\text { New Labour candidates not AWS } \\
\text { (male \& female) }\end{array}$ & $-23.90^{*}$ & $-7.07^{*}$ & $-2.93^{*}$ \\
\hline \multicolumn{4}{|l|}{ Opposition candidates } \\
\hline Gender Conservative candidate 2005 & & 0.33 & 0.28 \\
\hline Gender Lib Dem candidate 2005 & & -0.12 & 0.23 \\
\hline Scotland & & $6.49 *$ & $8.90^{*}$ \\
\hline Wales & & $2.78^{*}$ & $1.82^{*}$ \\
\hline \multicolumn{4}{|l|}{ Expenses } \\
\hline Scandal where MP not standing & & 1.40 & 1.00 \\
\hline $\begin{array}{l}\text { Moderate/excessive claims by } \\
\text { sitting MP }\end{array}$ & & -1.03 & -0.35 \\
\hline \multicolumn{4}{|l|}{ Social cleavages } \\
\hline FAC1: Urban working class & & $2.09^{*}$ & $-0.51^{*}$ \\
\hline FAC2: Deprivation & & $5.89^{*}$ & $1.85^{*}$ \\
\hline FAC3: Retirement \& rural & & $-3.53^{*}$ & $-0.50^{*}$ \\
\hline Muslim \% & & $-0.18^{*}$ & $0.20^{*}$ \\
\hline Full time students $\%$ & & 0.01 & 0.03 \\
\hline \multicolumn{4}{|l|}{ Local campaign } \\
\hline Labour spending & & $0.14^{*}$ & $0.04^{*}$ \\
\hline Conservative spending & & $-0.09 *$ & $-0.03^{*}$ \\
\hline Lib Dem spending & & $-0.09^{*}$ & $-0.02^{*}$ \\
\hline \multicolumn{4}{|l|}{ Previous vote share } \\
\hline \% Labour vote share 2005 & & - & $0.75^{*}$ \\
\hline $\mathrm{R}^{2}$ & 0.53 & 0.87 & 0.95 \\
\hline
\end{tabular}

Notes: Unstandardised coefficients, ${ }^{*} P<0.05 . \mathrm{N}=629$. Models do not include Buckingham, Glasgow NE and Thirsk \& Malton

\section{Differentiating AWS and Other New Candidates by Incumbency Status}

The findings so far suggest that there is no evidence of an overall AWS effect or any candidate sex effect and that AWS candidates and new candidates standing in vacant seats had a similar effect on Labour vote change from 2005 to 2010 . In some ways, this is not surprising given the earlier descriptive results. But while any overall AWS effect can be attributed to being a new candidate, earlier descriptive 
Table 8: Differentiating AWS and Other New Candidate Effect on 2010 Labour Support by Incumbency (Controlling for Prior Vote Share 2005 and Additional Covariates-All Seats)

\begin{tabular}{|c|c|c|c|}
\hline \multirow[b]{2}{*}{ Variables } & \multirow{2}{*}{$\begin{array}{l}\text { Labour } 2010 \\
\text { vote Share }\end{array}$} & \multicolumn{2}{|c|}{$\begin{array}{l}\text { Confidence } \\
\text { intervals }\end{array}$} \\
\hline & & Lower & Upper \\
\hline \multicolumn{4}{|l|}{ Model: AWS and other new candidates by incumbency } \\
\hline Constant & $6.76^{*}$ & 3.69 & 9.82 \\
\hline \multicolumn{4}{|l|}{ Base: Labour male \& female incumbent Candidates } \\
\hline All women shortlist 2010 incumbent & $-1.31^{*}$ & -2.51 & -0.12 \\
\hline All women shortlist 2010 non-incumbent & $-5.62^{*}$ & -7.42 & -3.82 \\
\hline New candidates incumbent seat (not AWS) & $-2.21^{*}$ & -3.26 & -1.16 \\
\hline New candidates non-incumbent seat (not AWS) & $-4.80^{*}$ & -6.20 & -3.41 \\
\hline R2 & 0.95 & & \\
\hline
\end{tabular}

Notes: Unstandardised coefficients, ${ }^{*} P<0.05 . \mathrm{N}=629$. Models do not include Buckingham, Glasgow NE and Thirsk \& Malton

results suggested that there was a clear difference in performance between those AWS candidates standing in Labour-held seats and other AWS candidates in nonincumbent seats. There was also circumstantial evidence that the latter also performed significantly worse than other new candidates standing in vacant seats. Even though Labour incumbent candidates (male and female) were the base category in these models, we might still expect new candidates to do better in Labour-held seats than in non-held seats. Given that roughly 70 per cent of AWS candidates stood in Labour-held seats, there is an expectation that the performance of AWS candidates could significantly vary by incumbent seat status.

In order to address the second and third hypotheses stated earlier, we rerun the regression model and report the coefficients and confidence intervals after controlling for prior vote share and the other covariates. The results are shown in Table 8. All the control variables behave in the hypothesised direction and the model itself explain 95 per cent of the variation in Labour vote share. As expected, all the coefficients were significant and negative, reiterating that all new candidates (both AWS and non-AWS) did worse than incumbent candidates. However, incumbency status seemed to matter. After taking account of being an AWS candidate, the additional penalty of being an AWS candidate in a non-incumbent seat on Labour support in 2010 relative to 2005 was roughly 4.31 (the difference between -5.62 and -1.31). The 95 per cent confidence intervals also reveal that there is a significant statistical difference between the two coefficients. AWS candidates did significantly worse where they stood in non-incumbent seats compared to those standing in Labour-held seats. Incumbent seat status also mattered for other new candidates standing in vacant seats. Both coefficients are significantly different from the base category (Labour incumbent candidates) but are also significantly different from each other. The 95 per cent confidence intervals show that new non-AWS candidates standing in non-incumbent vacant seats do significantly worse than those in 
incumbent seats. While AWS candidates standing in Labour-held seats perform better than new non-AWS candidates (difference between the coefficients was .90), the results show that they are not statistically different to each other (at the 95 per cent confidence level, using standard $t$-test). AWS candidates in non-incumbent seats also did not perform significantly worse than non-AWS candidates in similar seats. We can therefore conclude that even after taking account of incumbency status, there was no anti-AWS effect in the 2010 general election.

\section{Conclusion}

For the first time in 13 years, Labour faced the prospect of electoral defeat and losing its grip on power. With the Blaenau Gwent debacle still fresh in the memory and the normative arguments for and against AWS continuing unabated between parliamentary elections, Labour's commitment to the logic of equality guarantees was sure to be tested. Despite the apologies for Blaenau Gwent, Labour continued its AWS policy in 2010. Even though it lost a substantial number of parliamentary seats, Labour still increased its percentage of women MPs in parliament. While the renewed vigour of equality promotion by the other main parties, particularly the Conservatives, contributed to the number of women in parliament reaching record levels, it was undoubtedly Labour's policy of AWS that enabled a net gain of 2.5 per cent from 2005 to be achieved. In 2010, AWS delivered again, and while there were some seat losses, our findings suggest that there was no anti-AWS effect. Like the 2005 general election, any perceived AWS effect was not due to candidate sex but simply the result of being a new candidate. However, unlike 2005, candidate performance did vary by incumbency status. AWS candidates in Labour-held seats saw a decline in support relative to Labour incumbent candidates but this was significantly less than AWS candidates standing in non-incumbent seats. A similar pattern existed for new non-AWS candidates. But although AWS candidates standing in Labour-held seats performed marginally better than new non-AWS candidates, there was no significant difference between these candidate types. For the comparable new candidates in non-held seats, AWS candidates performed slightly worse, but as with the new candidates (AWS and non-AWS) in Labour-held seats, there was no significant difference between the two. Put simply, even after taking account of incumbency status, there was no anti-AWS effect.

Once again our findings suggest that Labour and other parties have little to fear from using AWS. There were no significant electoral consequences once other factors were taken into account and it remains highly effective in returning significantly higher numbers of women MPs to parliament quickly. For both Labour internally and parliament generally, it is clearly integral to any aspirations for parity of representation and achieving policy change. During the Labour period of government there was growing evidence that the presence of greater numbers of women MPs led to gender policy initiatives being pushed up the government's agenda (Childs 2004; Lovenduski 2005). And while gender scholarship has somewhat moved away from attempting to determine the mechanisms through which descriptive representation leads to substantive representation, evidence persists that there is a statistical relationship between the number of women representatives in parliament and the introduction of gender equality policy initiatives such as sex inequalities in the workplace (Annesley et al. 2010). ${ }^{5}$ 
The electoral fallout from the 2010 general election may prompt a more general move towards equality guarantees in time for the next election. With Labour likely to persist with AWS to achieve its goal of parity in the parliamentary party and internal pressure likely to grow for a debate on AWS for the Liberal Democrats given their decline in women MPs, the arguments about how women's descriptive representation in parliament can be enhanced are likely to continue. Perhaps the most interesting question is what the Conservatives will do between elections. Despite the giant leap forward since the election of Cameron, the Conservatives only selected just over a quarter of women in retirement seats at the 2010 election while women still compose less than a fifth of the Conservative parliamentary party. It is yet unclear whether the Conservatives would stomach further reforms and fully commit to equality guarantees. There also remains a lingering doubt over whether their (often less feminist) electorate would deter the party from adopting such a measure. Yet, one thing is clear: from the evidence of the past two general elections, they are unlikely to suffer a significant electoral penalty if they do decide to adopt AWS or equality guarantees in time for the next election.

\section{About the Authors}

David Cutts, Institute for Social Change, University of Manchester, 2.11 Humanities Bridgeford Street, Oxford Road, Manchester M13 9PL, UK, email: david.cutts@manchester.ac.uk

Paul Widdop, Institute for Social Change, University of Manchester, 2.11 Humanities Bridgeford Street, Oxford Road, Manchester M13 9PL, UK, email: Paul.Widdop@manchester.ac.uk

\section{Notes}

We wish to thank Professor Sarah Childs for providing details of the all women shortlist seats.

1. The former MPs in question are Anne Cryer (Keighley) and Tony Wright (Cannock Chase). A number of studies in the UK have shown that incumbents benefit from a personal vote (Cain et al. 1987; Norris et al. 1992).

2. In the first stage equation, we obtained the F-statistic using a linear model to test whether an instrument was weak or not. All our instruments recorded $F$-test values of less than 10 which indicate that they are weak. If we used these instruments in the IV model, the sampling distribution of the two stage least squares estimator would not be normal, resulting in misleading confidence intervals and unreliable estimates.

3. There was no evidence of multicollinearity at any stage of the modelling process. The average VIF for stage 2 of the model on Labour vote share is 1.42 compared with 1.86 in stage 3 . All tolerance statistics are well above 0.2 for all three models. Moreover, each predictor has most of its variance loading on a different dimension which is further indication of little or no multicollinearity.

4. Again we found no evidence of multicollinearity in any model. The average VIF for stage 2 of the model on Labour vote share is 1.54 compared with 1.99 in stage 3. All tolerance statistics are well above 0.2 for all models. Also each predictor has most of its variance loading on a different dimension which is further indication of little or no multicollinearity.

5. The authors stress that this finding does not represent a causal relationship between legislative representation and the adoption of gender equality policy agendas although they concede that further work is needed to determine the type of relationship between descriptive and substantive representation and how this relates to policy action (see Annesley et al. 2010).

\section{Bibliography}

Allison, P. (1990) 'Change scores as dependent variables in regression analysis', in C. Clogg (ed.), Sociological Methodology (Oxford: Blackwell), 93-114. 
Angrist, J., Guido, I. and Donald, R. (1996) 'Identification of causal effects using instrumental variables', Journal of the American Statistical Association, 91:434, 444-455.

Annesley, C., Engelli, I., Gains, F. and Resodihardjo, S. (2010) 'Gender equality policy advocacy in hard times: Comparing the determinants of issue attention to gender equality on policy agendas', paper presented to American Political Science Conference, Washington DC, 2-5 September.

Black, J. and Erickson, L. (2003) 'Women candidates and voter bias: Do women politicians need to be better?', Electoral Studies, 22:1, 81-100.

Bound, J., Jaeger, D. A. and Baker, R. (1995) 'Problems with instrumental variables estimation when the correlation between the instruments and the endogenous explanatory variable is weak', Journal of the American Statistical Association, 90, 443-450.

Bradbury, J. (2010) 'Wales and the 2010 general election', in A. Geddes and J. Tonge (eds), Britain Votes 2010 (Oxford: Oxford University Press), 143-157.

Cain, B., Ferejohn, J. and Fiorina, M. (1987) The Personal Vote: Constituency Service and Electoral Independence (Cambridge MA: Harvard University Press).

Campbell, R. and Childs, S. (2010) 'Wags, wives and mothers ... but what about women politicians?', Parliamentary Affairs, 63:4, 760-777.

Campbell, R. and Lovenduski, J. (2005) 'Winning women's votes? The incremental track to equality', in P. Norris and C. Wlezien (eds), Britain Votes 2005 (Oxford: Oxford University Press), 181-197.

Childs, S. (2003) 'The Sex Discrimination (Election Candidates) Act and its implications', Representation, 39:2, 83-92.

Childs, S. (2004) New Labour Women MPs (London: Routledge).

Childs, S. (2008) Women and British Party Politics (London: Routledge).

Childs, S. (2010) 'A missed opportunity? Women and the 2010 UK general election', IDS Bulletin, 41:5, 109-115.

Curtice, J., Fisher, S. and Steed, M. (2005) 'The results analysed', in D. Kavanagh and D. Butler (eds), The British General Election of 2005 (Basingstoke: Palgrave Macmillan), 235-259.

Cutts, D. (2006) 'Continuous activism and electoral outcomes: The Liberal Democrats in Bath', Political Geography, 25:1, 72-88.

Cutts, D., Childs, S. and Fieldhouse, E. (2008) “"This is what happens when you don't listen”: All women shortlists at the 2005 general election', Party Politics, 14:5, 575-595.

Denver, D. and Hands, G. (1997) Modern Constituency Electioneering (London: Frank Cass).

Duverger, M. (1955) The Political Role of Women (Paris: UNESCO).

Engstrom, R. (1987) 'District magnitudes and the election of women to the Irish Da'il', Electoral Studies, $6: 2,125-132$.

Fieldhouse, E. and Cutts, D. (2009) 'The effectiveness of local party campaigns in 2005: Combining evidence from campaign spending, agent survey data and individual level data', British Journal of Political Science, 39:1, 367-388.

Fieldhouse, E., Cutts, D. and Russell, A. (2006) 'Neither north nor south: The geography of Liberal Democrat voting in 2005', Journal of Elections and Public Opinion, 16:1, 77-92.

Fisher, J., Cutts, D. and Fieldhouse, E. (2011) 'The electoral effectiveness of constituency campaigning in the 2010 British general election: “the triumph" of Labour?', Electoral Studies, 30:4, 816-828.

Gerber, A. and Green, D. (2000) 'The effects of canvassing, telephone calls, and direct mail on voter turnout: A field experiment', American Political Science Review, 94:3, 653-663.

Guillaume, F., Maniquet, F. and Morelli, M. (2008) 'Incumbents' interests and gender quotas', American Journal of Political Science, 52:4, 891-907.

Imai, K. (2005) 'Do get-out-the-vote calls reduce turnout? The importance of statistical methods for field experiments', American Political Science Review, 99:2, 283-300.

Johnston, R. J., Pattie, C. J., Dorling, D., Rossiter, D., Tunstall, H. and MacAllister, I. (1998) 'New Labour landslide-same old electoral geography', in D. Denver, P. Cowley, J. Fisher and C. Pattie (eds), British Elections and Parties Review 8 (London: Frank Cass), 35-64.

Kelley, J. and McAllister, I. (1984) 'Ballot paper cues and the vote in Australia and Britain: Alphabetic voting, sex and title', Public Opinion Quarterly, 48, 452-466.

Krook, M. L. (2009) Quotas for Women in Politics (New York: Oxford University Press).

Lovenduski, J. (2001) 'Women and politics: Minority representation or critical mass?', in P. Norris (ed.), Britain Votes 2001 (Oxford: Oxford University Press), 179-194. 
Lovenduski, J. (2005) Feminising Politics (Cambridge: Polity Press).

Mansbridge, J. (1999) 'Should blacks represent blacks and women represent women? A contingent "yes"', Journal of Politics, 61:3, 628-657.

Mitchell, J. and van der Zwet, A. (2010) 'A Catenaccio game: The 2010 election in Scotland', Parliamentary Affairs, 63:4, 708-725.

Murray, R., Krook, M. L. and Opello, K. (2011) 'Why are gender quotas adopted? Party pragmatism and parity in France', Political Research Quarterly, OnlineFirst. DOI: 10.1177/1065912911414590.

Norris, P., Lovenduski, J. and Vallance, E. (1992) 'Do candidates make a difference?', Parliamentary Affairs, 45:4, 496-517.

Pattie, C. J. and Johnston, R. J. (2009) 'Still talking, but is anyone listening? The changing face of constituency campaigning in Britain, 1997-2005', Party Politics, 15:4, 411-434.

Phillips, A. (1995) The Politics of Presence (Oxford: Oxford University Press).

Phillips, A. (1998) Feminism and Politics (Oxford: Oxford University Press).

Rosenbaum, P. and Rubin, D. (1985) 'Constructing a control group using multivariate matched sampling methods that incorporate the propensity score', The American Statistician, 39:1, 33-38.

Squires, J. (2010) 'Gender and minority representation in parliament', Political Insight, 1:3, 82-84.

Whiteley, P. and Seyd, P. (2002) High Intensity Participation: The Dynamics of Party Activism in Britain (Ann Arbor MI: University of Michigan Press).

Wyn Jones, R. and Scully, R. (2010) 'What happened in the 2010 election?', Briefing, Wales Governance Centre, Cardiff University and Institute of Welsh Politics, Aberystwyth University, 26 May. 